\title{
PROBLEMS ASSOCIATED WITH THE DEVELOPMENT OF OVERSOWN TUSSOCK COUNTRY
}

\author{
R. M. SNOW \\ Farmer, Morven Hills Station, Tarras
}

MoRven Hills is situated 42 miles north-east of Cromwell on the Cromwell-Timaru state highway. The aspect of the country is one-third south-west, and the remainder northeast to north-west. Altitude ranges from 1,500 to $5,500 \mathrm{ft}$ a.s.l. Annual rainfall is approximately 22 in. but appears to be increasing. The area of Morven Hills is 35,000 acres of which 3,500 have been oversown, nearly all with seed as well as super-phosphate.

Before improvement work started in 1954, stock carried was 8,780 sheep and 88 cattle. 1965 stock figures are 10,239 sheep and 220 cattle. Surplus stock in 1954 was 797 sheep and 29 cattle; in 1965, 2,414 sheep and 71 cattle.

No cultivation is carried out and no winter feed is grown or bought. The first oversowing carried out was on the riverflats where superphosphate and lime were sown from the back of a $4 \times \mathbf{x} 4$ truck. Molybdenized superphosphate was also tried but no greater improvement in growth resulted. The main problem in this initial work was the replacement of spare parts, such as radiators and springs, because of the roughness of the terrain.

\section{Initial Development}

With the advent of the aeroplane, work was started on the hill blocks in 1957 the first block being sown with $11 / 2$ cwt of straight superphosphate and $3 \mathrm{lb}$ of white clover. Approximately half the block was oversown with outstanding success, but, unfortunately, sweet brier in the other half also responded to superphosphate and now looks like presenting a formidable problem.

The following year, parts of a further block were sown. However, this sowing was done prior to any subdivision fencing with the result that the improved country was really thrashed by the ewes and lambs while the remainder of the block was left practically untouched; in fact, the 
growth almost required burning. To counter this, a subdivision fence of nearly six miles was erected and the following autumn one side of this fence was spelled during January, February and March. An additional block of 450 to 500 acres on this side had been oversown the previous spring and the spelling also served to let the clover get well established prior to stocking.

\section{Pasture Species}

Since the first oversowing in 1957, field days in the Mackenzie Country have demonstrated impressive results from alsike clover, and a mixture of alsike, white clover and cocksfoot is now being used. Cocksfoot has proved much harder to get established, particularly if the ground has good cover before oversowing; also, it seems to require spelling for a complete autumn if possible as the sheep seem to pull out the young plants in the very early stages.

Under 'a pastoral lease, there was a stock limitation on the property of 9,000 sheep, plus some cattle until 1963. In that year, the limit was increased to 11,000 including 4,000 ewes and 200 cattle. While this increase was most welcome, there is little hope of growing sheep to increase the flock as quickly as it is possible to grow feed. However, feed can be grown for only a limited period of the year, October to May, as the clover on the improved areas does not stand up to the frosts in this region. Though cocksfoot does exceptionally well, there is an urgent need for a grass that will withstand frosts and can be established earlier and more easily than cocksfoot. This spring, ryegrass has been included in the mixture on one hill block but it is too early yet to predict the results. The crucial period is from July to September, and, in an effort to provide feed during this period, some of the drier faces facing north-west have been oversown this season. Again, there appears to be a definite need for newer varieties of grasses and clovers which will withstand better the dry hard conditions found in such aspects.

\section{Thrift of Sheep}

This last season, 1965-6, was one of the wettest experienced in the area for many years with the result that there was an abundance of feed on both unimproved and 
improved country; but, unfortunately, the sheep on improved land did not thrive. In fact, prior to shearing the hoggets in November, 1965, it was necessary to crutch all of them-the net result being one ton of dags. After shearing, all of these shorn hoggets were drenched with thiabendazole and returned to improved pasture for six weeks before being returned to their own block which had been burnt the previous spring. This is the first time it has been necessary to drench sheep on this property.

However, more was to follow, for, at weaning time in March, both ewes and lambs were in such poor condition, although running on partly improved country, that a veterinary surgeon was called in to examine them. He found the worm count in ewes practically non-existent and he did not recommend drenching them. However, in the lambs, the worm count warranted drenching and all lambs were drenched with thiabendazole and put on to a clean block of oversown tussock which had been shut up and kept for weaning. The ewes were turned out on to unimproved native country and left there till April, by which time they had picked up and looked more as they did prior to being on improved country. Also, at weaning, a few cases of footrot in the ewes were discovered, which was another reason for returning them to unimproved, drier country. This is only the second time that footrot has appeared on Morven Hills, and no doubt was brought about by the abundant feed and wet conditions.

A drenching trial was started at weaning time, 1966, with 120 hoggets taken from the main mob of hoggets. The results are shown in Table 1.

It can readily be seen that the best results were from thiabendazole followed by selenium, but it will be noted that in both cases it was not until the second drenching

TABLE 1: WEIGHT GAINS OF HOGGETS IN DRENCHING TRIAL

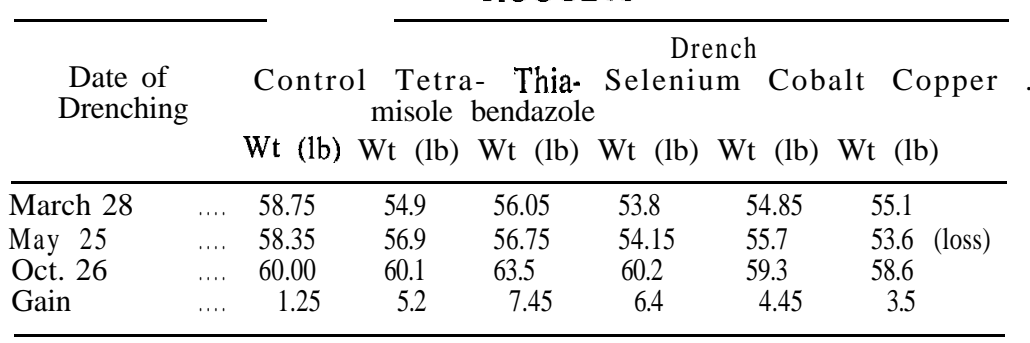


that the hoggets really started to go ahead and show a big increase over the control mob or other forms of drench. In the case of the mob treated with copper, it was found at the second weighing that they had actually lost weight, so they were not re-drenched.

As a result of the findings of this trial, the intention was to drench all the main mob of hoggets before shearing with a mixture of thiabendazole and selenium. In fact, all these hoggets were drenched in the autumn with thiabendazole and, judging by appearances, look as good as, if not better than any of the trial mobs of hoggets. After drenching and shearing, these hoggets will be put on to a saved block of improved tussock for 4 to 6 weeks before they are turned out on to the hill.

\section{Suitable Sheep Breed}

An interesting feature observed during the weighing of these hoggets was that while the heaviest in the mob was a cross-bred hogget, in most cases the fine-woolled of the merino hoggets were just as good as the stronger ones. So, at this stage of development, it is not intended to make any change in breed of stock. Once the merinos become adapted to the change in environment, and management policies are altered to suit, it should be possible to run them successfully on improved tussock grassland. At present, the wethers are allowed on to some of this improved country when they come down in the spring, and they remain there until shearing after which they are returned to their own block which runs up to 5,500 ft. So far, there has been no trouble whatsoever in getting them to stay back in the higher country; in fact, except for eyeclipping, they do not come off this block again until the following spring. Since oversowing, however, it is necessary to crutch all the wethers in May. This keeps them clean right through to shearing, while the extra expense of crutching is more than compensated for by the smaller amount of stained and dirty wool at shearing time. The older wethers, cast-for-age, are fattened on improved pasture and the majority are sold fat by March, space permitting.

While sales of surplus stock have increased considerably, there has been, at the same time, an attempt to increase stock numbers; and in order to maintain an even flock, 
it is still necessary to maintain a fairly high culling rate. This has been helped by the increase in lambing percentages which have risen from $68 \%$ in 1953 to $87 \%$ in 1964 .

The total wool production in 1953 was $82,245 \mathrm{lb}$, and in $1963,104,370 \mathrm{lb}$. The amount of wool cut per sheep now is possibly $1 / 2 \mathrm{lb}$ lower than before land improvement began; the total wool clip is much increased owing to larger stock numbers, and there is now a much higher percentage of breeding ewes in the flock.

\section{Finance}

One of the biggest problems in any scheme of improvement is finance. At Morven Hills, the aim has been to finance improvement work out of income, though a subsidy was received from the Catchment Board for the first subdivision fence erected. Given reasonably stable markets for produce, it is hoped to continue to maintain the improved areas and to develop further blocks out of income. At the same time, by borrowing, improvement work could go on so much faster. Which is the better method economically, is something best left to the economist to decide.

\section{I nsect Pests}

One of the biggest problems in the future must surely be the appearance of grass-grub and porina in areas of improved tussock land. Grass-grub first appeared on Morven Hills some two years ago, but pasture so far has recovered very well each spring from seed already in the ground. So far, no DDT or other chemicals have been applied on the assumption that it may be cheaper and more economical just to resow any areas which fail to come away by themselves.

Porina has made a most unwel come appearance this year, but there seems no economical, long-term treatment available as yet. However, by increasing stock numbers and grazing these areas much harder than in the past, it may be possible to help prevent the advent of grass-grub and porina.

\section{Sweet Brier}

A nother problem to be faced in the future is that of sweet brier. This is one of the real problems of tussock grass- 
land, whether improved or not. On Morven Hills, much good grazing land has been put out of production by this weed. Last summer, contractors sprayed a small area with picloram (Tordon $75 \mathrm{~T}$ ) and the results have been excellent. The costs of eliminating the brier, however, would not be regained from the amount of increase in production from the same area of land. Fortunately, most of the young briers left appear to be at least six years' old, and since then regeneration appears to have been much slower but, from experience, these bushes, no matter what age, really appreciate a burst or two of sulphur and superphosphate-even more so than grasses and clovers.

\section{Labour}

At present, work on the property is done by the writer, a permanent married man and two additional men for mustering. While tracks and fences have made for easier access and management, it will be necessary to employ more labour in the future, as there will be a change from musterers to shepherds and much more shifting of stock, both cattle and sheep, will be necessary to utilize to the full the extra feed grown on improved areas. Coupled with this is the fact that drenching, and in some years footrotting, have become necessary. Both of these tasks would be more readily handled with a larger labour force.

\section{Conclusions}

The "problems" discussed may be regarded rather as incentives that incite one to bigger and better things in tussock improvement. There have always been problems associated with farming tussock grassland. Some of these have been man made, others by nature, while others, such as out-of-season fires, just seem to occur, but, by a combined effort of scientists, research workers, farm advisors, stock firms, farmers, and all interested in tussock grassland, by the sharing of views and findings, production can be increased and this land handed on to our sons and their sons in much better heart and condition than it is at present.

\section{Acknowledgement}

The writer wishes to thank the Economic Service of the Meat and Wool Board for compilation of figures and for general help and co-operation. 


\section{DISCUSSION}

With improved pastures, is there a loss of palatability of clovers resulting in sheep ill-thrift?

No, I do not think so, as in some areas the clovers were eaten hard into the ground. Surplus feed in other areas was, I feel, the result of understocking rather than loss of palatability.

Sheep lost condition last year. Did this affect lambing percentage this year?

It did not appear to do so. Lambing was nearly $85 \%$ this year, which I consider good, although we have had better.

\section{Does Mr Snow envisage any wintering problems from carrying extra} stock as a result of his improvement programme?

Not in the foreseeable future as I have now started improving some of the sunnier and drier faces for winter use; also, subdivision has made it possible to shut up and save blocks for winter feed. 